\title{
News and Notices
}

\section{The Letter of the Madonna to the People of Messina in Chinese by the Jesuit Metello Saccano: An Unknown Seventeenth-Century Manuscript}

\author{
Agostino Giuliano \\ Museo Regionale di Messina \\ agostino.giuliano@regione.sicilia.it \\ Maurizio Scarpari \\ Ca' Foscari University of Venice, emeritus \\ scarparimaurizio@gmail.com
}

\begin{abstract}
The depository of the Regional Museum of Messina preserves a small, frail canvas bearing two inscriptions. The first, particularly fragmented, is in Italian in four lines, while the second is in Chinese characters in fourteen columns. The museum documentation provides no information regarding the manuscript's significance, author, origin, and period. This article shows that the manuscript is a Chinese version of the legendary Letter of the Madonna, the letter of protection that Mary is said to have delivered to a delegation from Messina that accompanied Paul the Apostle to Jerusalem. Furthermore, the article identifies the manuscript's author and the date of composition: the Sicilian Jesuit Metello Saccano (1612-62), a missionary in China and Cochin China from 1644 until his death. Intent on spreading the cult of the Madonna of the Letter, in the early 1660 , he sent this elegant Chinese version of the letter to Placido Giunta (1593-1674), his spiritual director and the rector of the Jesuit novitiate of Messina.
\end{abstract}

(C) AGOSTINO GIULIANO AND MAURIZIO SCARPARI, 2018 | DOI:10.1163/22141332-00504008

This is an open access article distributed under the terms of the prevailing CC-BY-NC license at the time of publication. 


\section{Keywords}

Letter of the Madonna - Madonna of the Letter - Chinese manuscript - Metello Saccano - Placido Giunta - Sicilian Jesuit missionaries - Eastern Indies - China Cochin China

From $^{1}$ among the hidden treasures of the Museo Regionale di Messina, a small ( $\mathrm{cm} 27 \mathrm{x} 23$ ) linen canvas covered with faded print has come to light, reduced by time to two large fragments and other smaller pieces, and on which can be read two painted inscriptions: the principal one, in Chinese characters, descends in vertical columns from right to left, occupying about four-fifths of the surface area; the second, a sort of title in Italian, in book fonts, is positioned above this on four horizontal lines (see Figure 1). The poor state of conservation reduces the legibility of both texts.

Very few references to the item have been located in the museum's archives. Registered in 1884 as a "pezzo di papiro con caratteri" (a piece of papyrus with characters), ${ }^{2}$ it is described in the mid-twentieth century as a "frammento di stoffa colorata con avanzi di scrittura in lingua italiana e cinese" (a fragment of coloured textile with scraps of writing in the Italian and the Chinese language), of unknown origin, datable to the nineteenth century. ${ }^{3}$ On the basis of the few available elements, it has now been possible to identify the item,

1 Several people have contributed in various ways to improve the present article and have offered useful insights, in particular Dr. Eugenio Menegon (Boston University). Other scholars who contributed to the research are mentioned in Agostino Giuliano and Maurizio Scarpari, "La Lettera della Madonna ai messinesi in lingua cinese di Metello Saccano: Un manoscritto inedito del XVII secolo," Archivio storico messinese 98 (2017): 7-45.

2 Archivio Museo Messina (hereafter AMM), Copia dei verbali di consegna al Museo Civico, MS (1908 post), 72. From the consignment notes of 1915 we learn that on that date Museo Nazionale di Messina, which had just then been established, received a box of objects that had been recovered from the ruins of the Museo Civico Peloritano after the earthquake of 1908; among other things had been found a "tela molto logora con scrittura orientale e la scritta in cui si legge: Compagnia di Gesù [thoroughly tattered canvas with oriental characters and an inscription reading: Society of Jesus]." See Aмм, Originali dei verbali di consegna al Museo, ms (1915 post), 151.

3 AM M, Inventario Accascina, MS, vol. 1 (1954), n. 1051. Dating already proposed in the old inventory of 1922, in which the manuscript is described as "Papiro (sic), tela colorita. In frantumi con avanzi di scrittura: 'in lingua [...] P. Placido [...] Compagnia di Gesù [...]' italiana e cinese” [Papyrus (sic), colored canvas. In fragments with scraps of writing: 'in language [...] P. Placido [...] Society of Jesus [...]' Italian and Chinese]." See Aмм, Inventario Mauceri, MS, vol. 2 (1922), no. 3564 . 


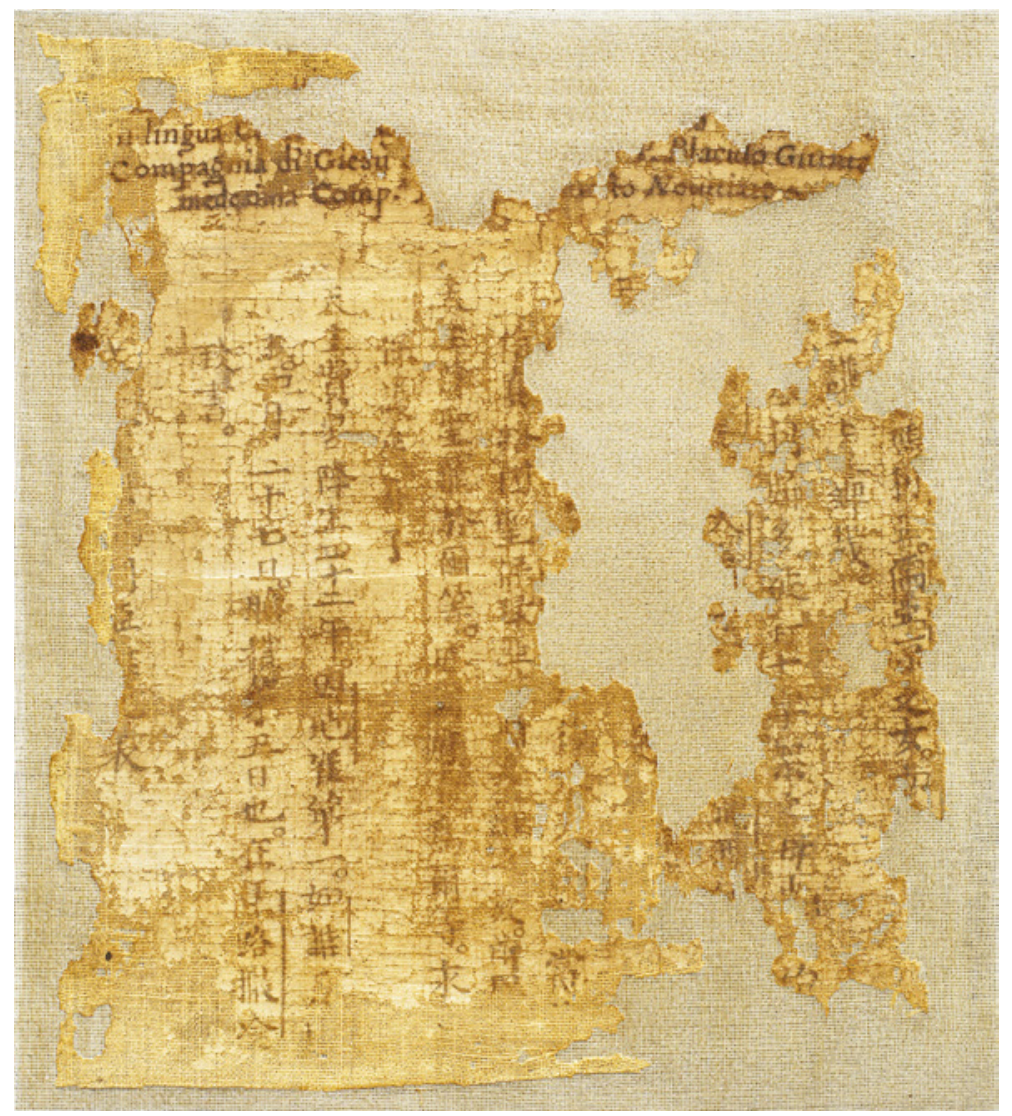

FIGURE 1 Manuscript after restoration. Mid-seventeenth century. Messina, Museo Regionale, inv. no. 1051 (by concession of Regione Siciliana, Assessorato dei Beni Culturalie della Identità siciliana -Dipartimento dei Beni Culturalie della Identità siciliana-Polo Regionale di Messina per i Siti Culturali-Museo Interdisciplinare di Messina).

its author, and the date of composition, and to piece together the events that brought it from the East Indies to Messina: the terms "Compagnia di Giesù" (Society of Jesus), "Noviziato" (Novitiate) and the name "P. Placido Giunta" can be discerned in the title; in the section in Chinese can be made out the name of the Virgin Mary, of her father Joachim, of Paul the Apostle, part of the date (the year 42, First Indiction), and the place where it was written (Jerusalem). It has been possible to decipher a considerable portion of the text. ${ }^{4}$

4 For a detailed examination and the translation of each single column, see Giuliano and Scarpari, "La Lettera della Madonna," 17-29. The text of the Letter and the translation from the Chinese are given in the Appendix. 
This document is a translation into Mandarin Chinese of the Lettera della Madonna (Letter of the Madonna) to the natives of Messina. A late-medieval religious tradition tells how in the year $42 \mathrm{CE}$, following the Apostle Paul's visit to Sicily, the people of Messina sent a delegation to the Madonna in Jerusalem. The Madonna gave the delegates a letter in Hebrew, later translated into Greek by Paul himself, in which she expresses her willingness to place the city of Messina and its inhabitants under her special protection, since they have shown their sincere conversion. While all traces of the Hebrew original had already been lost by the time of the "invasion of the Barbarians," the Greek copy of the Letter, lost for centuries in the city's archives, had come to light, according to the supporters of its authenticity, in the fifteenth century and was then translated into Latin by the erudite humanist Constantine Lascaris (1434-1501). The Greek exemplar would also be lost in the following century, while the oldest extant version of the Letter in Latin dates from $1556 .{ }^{5}$ The cult of the Letter and its feast (on June 3) are attested unequivocally only from the first half of the seventeenth century. ${ }^{6}$

By tracing the vicissitudes of Placido Giunta, a Jesuit of Messina born at Valdina in 1593, who died in an odor of sanctity at Messina in 1674-a wellknown figure in the city, so highly esteemed that he became known as the

5 The oldest extant version of the Letter is that provided at the end of the work by the abbot Francesco Maurolico (1494-1575), Vita Christi Salvatoris eiusque matris sanctissime: Senariis rhithmis correcta multisque additionibus necessariis illustrata; Gesta apostolorum et sanctorum nuper eodem rhytmorum genere composita (Venice: Agustino Bindoni, 1556), 52 ${ }^{\mathrm{v}}$, that is found again with some variants both in the exemplar of 1599 discovered in the Messina ecclesiastical archives, extracted from the Libro privilegiorum nobilis urbis Messanae, and in those reported by Giuseppe Buonfiglio and Costanzo, Messina città nobilissima (Venice: Gio. Antonio e Giacomo de Franceschi, 1606), 56 $6^{\mathrm{v}}$, and by Placido Samperi, Iconologia della gloriosa Vergine Madre di Dio Maria Protettrice di Messina (Messina: Giacomo Matthei Stampatore Camerale, 1644), 74-75.

6 There is a huge amount of literature on this subject. For a recent overview of the genesis of this devotion, see Giovan Giuseppe Mellusi, "Dalla Lettera della Madonna alla Madonna della Lettera," Archivio storico messinese 93 (2012): 237-61. The studies on the historic phenomenon of the Madonna della Lettera nearly all agree in considering it an attempt by the dominant ruling classes of Messina to reaffirm the real or presumed superiority of their city over other Sicilian towns and in particular Palermo, which at the time of the institution of the Norman regnum had been recognized as Caput Siciliae. For a comprehensive overview of the issues and bibliography pertaining to the political-cultural polemic triggered by the Letter, see Giuseppe Lipari, "La Madonna della Lettera nella cultura messinese," in Arte, storia e tradizione nella devozione alla Madonna, ed. Giovanni Molonia (Messina: Tipografia Spignolo, 1995), 69-79. 
"apostle of Messina"7 - it was eventually possible to identify the role of his pupil Metello Saccano (1612-62), who joined the Society of Jesus at nineteen years and set out, aged just over thirty, for the missions in the East Indies, where he died in mysterious circumstances (likewise with a reputation for holiness). ${ }^{8}$ Saccano was a special case in the Jesuit world of that epoch, both on account of his (almost obsessive) desire to go to Japan, scornful of the dangers that he would likely encounter-considering the extremely difficult situation contemporary missionaries found in the Land of the Rising Sun —and also for his

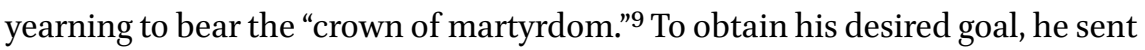
fifty-eight litterae indipetae (a higher number than was usual for the period) to the General Curia in Rome, whose task was to choose missionaries to send to the East Indies. ${ }^{10}$ This possibility was denied him, but he was permitted to go to the missions in China, at Macao and in Cochin China. He set sail for Lisbon on March 30, 1643. Concerning the last months of his life, however, there exists some doubt. According to the official documentation he died in Cochin China on August 7 or 17, 1662. The lack of any reference to martyrdom, a reason for pride often emphasized by the Society for propaganda purposes, might suggest that he died of more or less natural causes. However, the Sicilian Jesuit and historian Emanuele Aguilera (1677-1740), in his history of the Society of Jesus in Sicily, referred to the authoritative testimony of Father Prospero Intorcetta

7 Giuliano and Scarpari, "La Lettera della Madonna," 11-17.

8 Ibid., 33-39. There is no evidence of canonization processes for either Placido Giunta or Metello Saccano in the archives of the Congregazione delle Cause dei Santi (private communication dated May 28, 2018, prot. var. 8256/18). Nevertheless, the name Placido Giunta appears on page 626 of the list included in Giuseppe Maria Brocchi, Vite de' Santi e Beati fiorentini (Florence: Gaetano Albizzini, 1742) that bears the names of the "Santi, beati, e venerabili servi di Dio, i quali o per origine, o per domicilio alla nostra città, ed alla nostra diocesi con qualche giusto motivo ascriver si possano [Saints, blessed and venerable servants of God, who either by being born or resident in our city, or in our diocese, with some good reason could be ascribed herein]" (viii), as indeed was the Giunta family, originally from Florence but which moved to Sicily well before Placido's birth.

On Jesuit candidates to extra-European missions, see Emanuele Colombo and Marina Massimi, In viaggio: Gesuiti italiani candidati alle missioni tra Antica e Nuova Compagnia (Milan: Il Sole 24 Ore, 2014).

On Saccano's indipetae, see Franca Berbenni, "La tenacia premiata: Metello Saccano, gesuita candidato alle missioni" (BA thesis, University of Milan, 2005-6). On the process of the writing of the indipetae by Saccano and the group of Jesuits from the college of Palermo in the early 1640 s, see Emanuele Colombo, "Repetita iuvant: Le litterae indipetae di Metello Saccano (1612-1662) e compagni," in Scrivere lettere: Religiosi e pratiche epistolari tra il XVI e il XVII secolo, ed. Pierluigi Giovannucci (Padua: Padova University Press, 2018), $69-92$. 
(1625-96), a Sicilian missionary in China from 1658 who, on the occasion of his brief return to Italy in the period 1669-73, reported that during the last year of his life Metello Saccano never gave up the idea of going to Japan, and that after several failed attempts he finally managed to land. It is believed he was shortly captured and put in prison, where he underwent all kinds of torture, up to his death. ${ }^{11}$

It is difficult to say where the truth lies. If we lend credit to Intorcetta's testimony, and in the light of Saccano's tenacious and obstinate personality, we may voice the hypothesis, impossible to prove, that having obtained permission to return to Cochin China, he had taken advantage of the occasion to attempt, even without the consent of his superiors, to reach Japan to fulfil his apostolic dream: to obtain absolution of his real or presumed sins through martyrdom. That would explain the silence in the official sources; for, if that is the case, Saccano, while having transgressed his vow of obedience, did not deserve to be ostracized, in virtue of his dedication during twenty years as a missionary in the East Indies, widely recognized by the upper echelons of the Society.

Whatever the case may be, the figure of the Jesuit of Messina gradually caught the attention of much of the city's population, who considered he had all the traits necessary to aspire to sanctification, including certain "miraculous" events that had happened in Cochin China thanks to his merits, such as the restitution of sight to a blind person, ${ }^{12}$ confirmed by the Inventario delle reliquie (Inventory of relics) in the Cathedral of Messina, among which is a copy of a letter "scritta in lingua Cinese mandata dal $\mathrm{M}^{\mathrm{o}}: \mathrm{R}^{\mathrm{o}}: \mathrm{P}^{\mathrm{e}}$. Metello Saccano della Compagnia di Gesù Messinese che fu Missionario nella Cina, e visse, e morì con fama di Santità" (written in the Chinese language, sent by $\mathrm{M}^{\mathrm{o}}: \mathrm{R}^{\circ}: \mathrm{Pe}^{\mathrm{e}}$. Metello Saccano of the Society of Jesus of Messina, who was a missionary in China, and lived and died under an aura of sanctity). ${ }^{13}$ This holy aura increased at the beginning of the eighteenth century, thanks as well to the first Jesuit biographies concerning the missionary, and increasing still further with the elevation to the status of relic of his Letter in Chinese.

\footnotetext{
11 Emmanuele Aguilera, Provinciae Siculae Societatis Jesu ortus, et res gestae: Ab anno 1612 ad annum 1672; Pars secunda (Palermo: Angelo Felicella, 1740), 821.

12 Benedetto Chiarello, Memorie sacre della città di Messina (Messina: Vincenzo D'Amico, 1705), 380, who reports what was related by P. De Marini on reaching Rome.

13 Archivio Cattedrale di Messina, Inventario delle Reliquie si conservano nella Protometropolitana Chiesa della nob: Fideliss ${ }^{a}$ : Ed esemplare Capitale Città di Messina (n.p., 1728), Ms, f. 18. At present, we are not able to establish if this is the small canvas that is the object of the present study, or an accurate copy of it. In biographical sources, when referring to the Letter in Chinese, scholars always speak of an "exemplar" and never of a "copy." Today there is no copy of the Letter among the reliquaries of the church.
} 
Saccano maintained a strong relationship with his master Placido Giunta, whom he considered his guide, both from the spiritual and the doctrinal point of view, as made evident in various letters sent during his stay in the Indies. It was to testify to his long friendship with him and to his own devotion to the cult of the Madonna della Lettera that Saccano sent the Letter in Chinese to Messina, dedicating it expressly to his spiritual father.

The translation of the Letter into Chinese was already being spoken of shortly after Saccano's death, in the historic-apologetic work on the city of Messina by Placido Reina in $1668,{ }^{14}$ and we can find traces in other sources over the following centuries, up to its arrival in the Archivio del Senato di Messina "per dono degli eredi di Luciano Foti nel 1798" (thanks to a donation by the heirs of Luciano Foti in 1798). ${ }^{15}$ This new location allows us very likely to understand when and how the manuscript arrived at the Museo Civico Peloritano, taking account of the fact that this museum had been established at the behest of the Senate in 1806 and that over the years various historic objects pertaining to the city had found their way there. Although we cannot ascertain the exact date of its arrival, we may be sure that by 1884 , when the old custodian Spiridione Cortimiglia handed over the keys to his successor, Antonino Rizzotti, the item was in the museum, probably already in such a poor state of conservation as to not enable its identification as the exemplar in Chinese of the Letter, the memory of which had evidently been lost with the passing of time. ${ }^{16}$ From the Museo Civico Peloritano, following the tragic earthquake of 1908, it ended up in the Museo Nazionale di Messina (1915), today's Regional Museum.

\section{Conclusion}

The Chinese language translation of the Letter was personally carried out by Metello Saccano or under his direct supervision, probably when he was at Macao, perhaps in the July $1644-$ February 1646 period. ${ }^{17}$ Over time, it had

14 Placido Reina, Notitie istoriche della città di Messina: Seconda parte (Messina: Paolo Bonacota, 1668), 530.

15 Caio Domenico Gallo, Annali della città di Messina capitale del Regno di Sicilia (Messina: Letterio Fiumara e Giuseppe Nobolo, 1804), 3:416-17. Luciano Foti (1694-1779) was a painter, restorer, antiquarian, and collector of pictures, especially of drawings and manuscripts that he gathered after the plague that hit Messina in 1743. See Gioacchino Barbera, Foti Luciano, in Dizionario biografico degli italiani (Rome: Treccani, 1997), 49:514-15.

16 Амм, Copia dei verbali di consegna, 72.

17 Giuliano and Scarpari, "La Lettera della Madonna," 40-41. 
become customary to translate the Letter into different languages to facilitate its spread throughout the world. ${ }^{18}$ Almost certainly, paper copies of the text in Chinese were used to spread the cult of the Madonna della Lettera in China and in Cochin China, where Saccano was from February 1646 to September 1654. The text was copied "in a fine version" on canvas - a highly regarded medium at the time, confirming the importance attributed to the translation, considering the precarious existence of the Jesuits in China - with the title written in Italian as a dedication: the text was intended as a gift for Placido Giunta, himself a devout supporter of the Madonna della Lettera.

It is not possible to establish with certainty when the canvas was sent to Messina, whether during one of Saccano's sojourns in Macao or during the time of his residency in the 1655-59 period at Makassar and at Sumba, in Indonesia. ${ }^{19}$ The period between 1655 , when Giunta was nominated Rector of the Noviziato di Messina, and 1662, the year of Saccano's death, seems the most likely: the name of Placido Giunta in the manuscript's title, in fact, seems to be placed in strict relation to the term "Noviziato." What is certain is that it is not merely a tool for a fervent missionary to spread devotion to the Madonna della Lettera in the lands of the East, but also, and perhaps above all, the personal gift to a master, a clear sign of a profound relationship and of deep gratitude.

18 This is discussed in Orazio Turriano, Ragguaglio della festa celebrata dalla nobile, fedelissima, ed esemplare Città di Messina: Nell'anno corrente 1729; In commemorazione della Sacra Lettera scrittale da Maria Sempre Vergine sua perpetua protettrice (Messina: Chiaramonte e Provenzano, n.d.), 13, 28; Giuseppe La Farina, Brevi notizie delle pompe eseguite in Messina per la festività di N. Donna della Lettera negli anni 1685 e 1742 (Messina: Giuseppe Fiumara, 1841), 29.

19 In September 1654, Saccano was in Macao to participate in a provincial congregation, at which he was elected procurator responsible for reporting to Rome on the state of the missions in the province of Japan. Setting sail from Macao at the beginning of January 1655, after a few days his ship ran into a terrible storm near Makassar and was wrecked with the loss of 150 people. Saccano was saved, together with a few others, by a small boat, though he lost the documents for his report to Rome. In the vain hope that the indispensable documents would be re-sent from Macao, Saccano waited in Makassar until March $165^{8}$ when, after the destruction of the Jesuit church, carried out on the orders of the local Muslim authority, he started a new mission on the island of Sumba in the Lesser Sunda Islands. However, owing to environmental and social problems there, the attempt did not prove fruitful and Saccano left the island in October 1659 and was called back to Macao. There, he became the vice rector of the Jesuit college from the beginning of September 1660 until March 31, 1662, when he returned to Cochin China. 


\section{Appendix}

For the transcription of the Chinese text see Figure 2. The text is set out in the traditional manner, in a sequence of columns that read right to left and from up to down, of variable length, composed of 2 (col. 13) to 19 (col. 11) characters. The refined style of writing would lead one to think that the manuscript was produced by a cultivated Chinese or by an expert scribe. The structure of the text is sufficiently clear, despite the poor condition of the canvas: we have 14 columns and about a hundred legible characters out of an estimated total of 150-70. Three columns have been lost owing to the ruined or missing fabric (5-7), three are severely damaged but show partial or faded traces of characters $(2,4,14)$, two are to some extent complete and enable the reading of short sections of text $(1,3)$, and the remaining six $(8-13)$ are in a good state of conservation and form a homogeneous block of 77 characters, some of which are faded or incomplete but on the whole decipherable.

\begin{tabular}{|c|c|c|c|c|c|c|c|c|c|c|c|c|c|}
\hline 14 & 13 & 12 & 11 & 10 & 9 & 8 & 7 & 6 & 5 & 4 & 3 & 2 & 1 \\
\hline $\begin{array}{l}\square \\
\square \\
\square \\
\square \\
\square \\
\text { 墭 } \\
\text { 亞 } \\
\square \\
\square \\
\square \\
\square\end{array}$ & $\begin{array}{l}\text { 欽 } \\
\text { 要 }\end{array}$ & 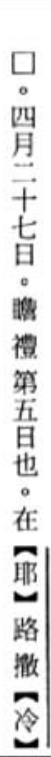 & 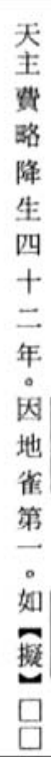 & $\begin{array}{l}\text { 保 } \\
\text { 護 } \\
\text { 於 } \\
\text { 吾 } \\
\text { 子 }\end{array}$ & 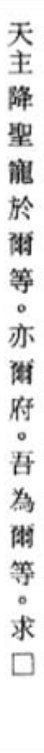 & $\begin{array}{l}\text { 信 } \\
\text { 真 } \\
\text { 路 } \\
\text { 因 } \\
\text { 啝 } \\
\text { 球 } \\
\text { 亞 } \\
\text { 波 } \\
\text { 斯 } \\
\text { 羅 } \\
\text { 之 } \\
\text { 教 } \\
\square \\
\square \\
\square\end{array}$ & $\begin{array}{l}\square \\
\square \\
\square \\
\square \\
\square \\
\square \\
\square \\
\square\end{array}$ & 丙 & $\begin{array}{l}\square \\
\square\end{array}$ & $\begin{array}{l}\text { 미 } \\
\text { 미 } \\
\square\end{array}$ & 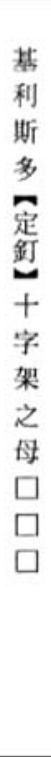 & $\begin{array}{l}\square \\
\square \\
\square \\
\square \\
\square \\
0\end{array}$ & $\begin{array}{l}\text { 瑪 } \\
\text { 利 } \\
\text { 亞 } \\
\text { 虂 } \\
\text { 京 } \\
\text { 之 } \\
\text { 女 } \\
\dot{0}\end{array}$ \\
\hline
\end{tabular}

FIGURE 2 Transcription of the Chinese text. The punctuation in the shape of a circle and the vertical lines that appear along the right side of some characters are present in the manuscript. Elements that have been added to the original are the progressive numbering of the columns, from 1 to 14, the square brackets in boldface, 【 】, inside of which is a character that, though only partly legible, has in any case been identified, the square, $\square$, indicating the presence of a non-identifiable character or not certainly identifiable, and three dots, [...], which indicate an imprecise number of characters irremediably lost. 


\section{Chinese Translation of the Lettera della Madonna}

[...] Mary, daughter of Joachim [...] Mother of Christ [...] fixed by nails to the cross $[\ldots]$

the way of the truth, through the preaching of Paul the Apostle electus (the chosen). ${ }^{20}$ The Lord of Heaven sends His blessing to you all, and also to your city. We for all of you beg [...] protection. ${ }^{21}$

In the year 42 of Our Son, made incarnate as the Son of the Lord of Heaven. ${ }^{22}$ First Indiction. June [...]

20 Shèng Băolù 聖保淥, followed by yàbōsìduōluó 亞波斯多羅, transliteration of "apostolus." In the earliest versions of the Letter (1556, 1599 and 16o6; see here footnote 4) can be read "Pauli Apostoli electi," while in that of 1644 more simply "Pauli, electi." The version used for the translation in Chinese was therefore one of the earliest. In the Chinese text, there is no mention of the term electus; there appears instead shèng 聖 “to be wise, a wise man” in front of Băolù 保淥, an expression that in traditional Chinese literature indicates the highest level of intellectual skill, morality, and spirituality that an individual may reach. Despite the undoubted points of contact that can be observed between the semantic sphere and the concept of shèng 聖 in the Chinese tradition, and of "saint" in the Christian one, these terms can only partly be considered equivalent. To the Jesuits, shèng 聖 seemed however to be the closest term to the concept of "saint" and, therefore, they adopted it to signify the saints of the Christian tradition; consequently, not only in present-day ecclesiastical Chinese but also in modern bilingual dictionaries, this meaning is present as well, alongside that of "wise." In the light of these considerations, it is understandable that, as Paul has for centuries been called "Saint Paul" in the West, it must have seemed obvious to whoever undertook the Chinese rendition of the Letter to maintain the linguistic unity between the name (Paolo) and its appellative (Saint), sacrificing therefore electus, "the chosen one, eminent, excellent, superior" in favor of shèng 聖, with the meaning therefore halfway between "wise man-saint" and "eminent-excellent." If that were not the case, it would be an evident anachronism.

Although continuing to follow the Latin text, this passage departs from it somewhat: consistent with what is indicated in the incipit of the Letter, in fact, it here makes it explicit that the benediction comes from the Lord of Heaven (Tiänzhǔ 天主) and reaches man through the intercession of the Virgin Mary.

The complexity of the theological assumptions comes through in the translation of the expression "filii nostri": wúzı̀ 吾子 “My/Our Son" spoken by Mary, placed before Tiānzhǔ 天主 “Lord of Heaven," and Fèilüe 費略 “Son” of God, a transliteration of the theological concept "Filius" in the Trinity, after Tiānzhǔ 天主; furthermore, the concept is introduced—not present at this point in the Latin original—of jiàngshēng 降生 "made incarnate, incarnation." Thus, it was intended in this way to affirm the double nature of Jesus: his being at the same time son of a woman (wúž̌ 吾子) and Son of God (Tiānzhǔ Fèilüè 天主費略), and through the mystery of the incarnation (jiàngshēng 降生) to emphasize the importance of the coming of the Son of God who, within the Trinity, participates in an eternal dimension and is timeless in historic time. 
Written and signed (by order of the Virgin Mary).

$[\ldots]$ Mary $[\ldots]$

\section{Lettera della Madonna of $155^{23}$}

Maria virgo, Ioachim filia, Dei humillima Christi Jesu crucifixi mater, ex tribu Iuda, stirpe David, Messanensibus omnibus salutem, et Dei patris omnipotentis benedictionem. Vos omnes fide magna legatos, ac nuncios per publicum documentum ad nos misisse constat: filium nostrum Dei genitum Deum et hominem esse fatemini, et in celum post suam resurrectionem ascendisse, Pauli Apostoli electi prcedicatione mediante viam veritatis agnoscentes. Ob quod vos et ipsam civitatem benedicimus, cuius perpetuam protectricem nos esse volumus. Anno filii nostri. XXXXII. Ind. Prima Tertio nonas Iunii. Luna XXVII. Feria quinta. Ex Hierosolymis. Maria virgo quce supra hoc presens Chirographum, approbamus.

English Translation of the Lettera della Madonna

I, Virgin Mary, daughter of Joachim, most humble servant of God, Mother of Jesus Christ crucified, of the tribe of Judah, of the offspring of David, health to all the people of Messina, and the blessing of God, the Father Almighty.

It is acknowledged by public documents that you all, with great faith, have sent to us emissaries and ambassadors. You confess that our Son, the onlybegotten of God, be God and man, and that after his resurrection he ascended to Heaven, showing you the way of the truth through the preaching of Paul the Apostle electus (the chosen). For this I bestow my blessing upon you and your city, of which I wish to be the perpetual protector. The year of our Son 42, Indiction I, June 3, XXVII of the moon, Thursday, from Jerusalem.

Mary the Virgin, who ordered the handwriting above and signs by her own hand.

23 Maurolico, Vita Christi Salvatoris, $5^{2}$. 
